International Journal of Current Advanced Research

ISSN: O: 2319-6475, ISSN: P: 2319 - 6505, Impact Factor: SJIF: 5.995

Available Online at www.journalijcar.org

Volume 6; Issue 3; March 2017; Page No. 2719-2720

DOI: http://dx.doi.org/10.24327/ijcar.2017.2720.0087

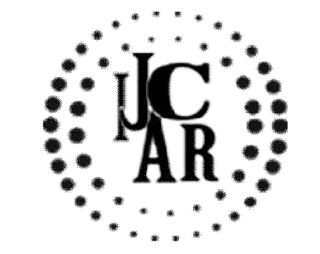

Research Article

\title{
EFFECT OF OREGANO ON IRREGULAR MENSTRUAL CYCLE
}

\author{
Nancy Selva V Mary and Jothi Priya A
}

Saveetha Dental College and Hospitals, Chennai, India

\section{A R T I C L E I N F O \\ Article History: \\ Received $10^{\text {th }}$ December, 2016 \\ Received in revised form $24^{\text {th }}$ January, 2017 \\ Accepted $17^{\text {th }}$ February, 2017 \\ Published online $28^{\text {th }}$ March, 2017}

\section{Key words:}

Menstrual cycle, Oregano seeds,

irregular menstrual cycle.

\begin{abstract}
A B S T R A C T
To determine the level of satisfaction the effect of oregano water in irregular menstrual cycle. To do a study on 50 women in Chennai who have irregular menstrual cycle by giving oregano water to them. The study involves around 20 questions on various effect of drinking oregano water and knowledge about their personal health.The study focused on irregular menstrual cycle in women. Since irregular menstrual cycle is very common among developed population due to obesity many women difficult to face many situations. now a days irregular menstrual cycle is common findings in women among $40-50 \%$.So by giving oregano water to cure the problem.
\end{abstract}

Copyright $₫ 2017$ Nancy Selva V Mary and A .Jothi Priya. This is an open access article distributed under the Creative Commons Attribution License, which permits unrestricted use, distribution, and reproduction in any medium, provided the original work is properly cited.

\section{INTRODUCTION}

Oregano (Trachyspermumammi) is a native of Egypt and is cultivated in Ivag, India, Afhganistan and Ivan. In India, it is cultivated in Madhya Pradesh, Uttarpradesh, Gujarat, Rajasthan, Maharashtra and West Bengal. Trachyspermumammi L. Belonging to family apricea is a highy valued medicinally Important seed spice. The roots are diuretic in nature and the seeds possess excellent aphrodisiac properties. [2] The seeds contain $2-4-4 \%$ brown coloured oil known as oregano oil. The main component of the seed is thymol. The thymol exhibits fungicidal, antimicrobial and ant aggregatory effect on human. [1] Oregano is the traditional potential herb and is widely used for curing various diseases in human and animals. The seed of Oregano is bitter, pungent and it acts as anthelmintic, Caramative, laxative and stomachic.[5] It is also used to cure abdominal tumour, abdominal pain and abdominal piles. Seed contain essential oil containing $50 \%$ thymol the seed is used with water to relieve women from the irregular Menstrual cycle. When periods (menstruations) come regularly, this is called the menstrual cycle. Having regular menstrual cycles is a sign that important parts of your body are working normally. [9] The menstrual cycle provides important body chemicals, called hormones, to keep you healthy. It also prepares your body for pregnancy each month. A cycle is counted from the first day of 1 period to the first day of the next period. The average menstrual cycle is 28 days long. Cycles can range anywhere from 21 to 35 days in adults and from 21 to 45 days in young teens.

*Corresponding author: Nancy Selva V Mary Saveetha Dental College and Hospitals, Chennai, India
In the first half of the cycle, levels of estrogen (the "female hormone") start to rise. Estrogen plays an important role in keeping you healthy, especially by helping you to build strong bones and to help keep them strong as you get older. When this cycle skips or moves long away know as irregular menstrual cycle it leads to many problems in women's health

\section{MATERIALS AND METHODS}

A cross sectional study was conducted in women in Tamilnadu. The study include Rural, Urban, Subareas. The areas are chennai, Thiruvalluvar, thiruthani, Kanchipuram, Avadi. The study was carried by giving Organo seeds water to womens who suffering from irregular menstrual cycle.

The Oregano seed water was given to women in the study period of 2 months and the questionnaire based interview was done after one month of drinking Oregano seed water. So then only they can able to feel differences and changes in their menstrual cycle. Every morning with empty stomach the oregano seed water to be taken. $50 \mathrm{gm}$ of Oregano seeds should be put inane glass of boiled water after five minute Oregano seeds should be filtered and remaining water to be taken by the participate. After one month the questionnaire interview will be done.

\section{RESULT AND DISCUSSION}

Fifty womens are participated for the survey it contains 20 questionnaire it contain few data into personal health and effect of Oregano water in irregular menstrual cycle. The result shows that before drinking of Oregano seed water $68 \%$ of women have a irregular menstrual cycle and 32\% women have a regular menstrual on the study period. After one month 
of drinking Oregano water $84 \%$ of women got a regular Menstrual cycle and $16 \%$ of them got regular menstrual cycle. The result shows that the $84 \%$ of women are cured. The study mainly focused on irregular menstrual cycle in women. Since irregular menstrual cycle is very common among developed population due to obesity many women are difficult to face many situation. Nowadays irregular menstrual cycle is common finding sin women among $40-50 \%$. So by giving Oregano water to cure the problem.

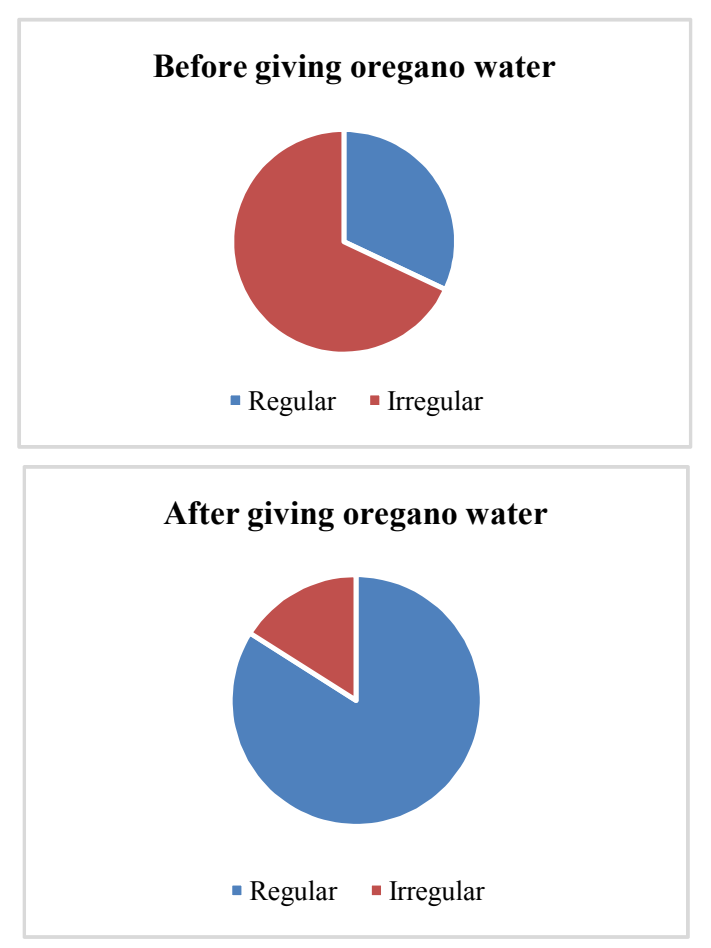

\section{Reference}

1. Long and highly irregular menstrual cycle as a marker risk of type (JAMA -2001)

2. Menstrual cycle irregularly and risk for future ca (J chin endocrimolmetab-2002)

3. Kaur $\mathrm{H}$ Estrogenic activity of some herbal galactogogue. Constituents Indian J AnimNutr

4. Joshi SG. Medicinal plants New Delhi, Idhi, Oxford nd IBH publishing Co. Pvt Ltd.,

5. Troy LM, Hunter DJ, Manson JE, Colditz GA, Stampfer MJ, Willett WC. The validity of recalled weight among younger women. Int J ObesRelatMetab Disord. 1995;19:570-572

6. Ehrmann DA, Barnes RB, Rosenfield RL. et al. Prevalence of impaired glucose tolerance and diabetes in women with polycystic ovary syndrome. Diabetes Care. 1999; 22:141-146.

7. Chang RJ, Katz SE. Diagnosis of polycystic ovary syndrome. EndocrinolMetabClin North Am.1999; 28: 397-408.

8. Chasan-Taber L, Willett WC, Stampfer MJ. et al. A prospective study of oral contraceptives and noninsulin-dependent diabetes mellitus among US women. Diabetes Care. 1997; 20:330-335.

9. Singh KB. Menstrual disorders in college students. Am J Obstet Gynecol.1981; 140:299-302.

10. Legro RS. Polycystic ovary syndrome: current and future treatment paradigms. Am J ObstetGynecol. 1998;179:S101-S

\section{Please cite this article in press as:}

Nancy Selva V Mary and Jothi Priya A (2017), Effect of Oregano on Irregular Menstrual Cycle, International Journal of Current Advanced Research, 6(3), pp. 2719-2720.

http://dx.doi.org/10.24327/ijcar.2017. 2720.0087 